\title{
How to put forest and conservation genomics into motion for and with Indigenous communities?
}

\author{
by Lyne Touchette ${ }^{1,2}$, Jean-Michel Beaudoin ${ }^{1,3}$, Nathalie Isabel2,"*, Nancy Gélinas ${ }^{1}$ and Ilga Porth ${ }^{1}$
}

\begin{abstract}
Sustainable management and conservation (SMC) projects for natural resources in collaboration with Indigenous Peoples using a genomics approach are increasing in number. Information and tools/applications derived from genomics can be useful to them, particularly in the context of climate change. However, the challenge of translating these applications into practice and harnessing them to serve Indigenous communities remains. We present an exploratory literature review that addresses: (1) the demonstrated utility of genomics in SMC projects involving Indigenous Peoples, (2) some issues that may limit the adoption of genomics tools, and (3) the collaborative work between researchers and Indigenous communities in the analyzed studies. The demonstrated uses identified were largely of a socioecological nature. The complementary nature of Indigenous knowledge and scientific knowledge in genomics was recognized as an opportunity that should be further developed to address current challenges such as climate change. Regarding the adoption into practice of this technology in SMC projects, in addition to similar issues with other end users, the integration of the needs, traditional values and knowledge of Indigenous communities in genomics projects also represents a challenge in the context of the decolonization of genomics research. Finally, community-researcher collaboration was identified as a key element in promoting the successful uptake of genomics in SMC.
\end{abstract}

Keywords: Indigenous Peoples, forestry and wildlife management, genomics applications, genetics, adaptation, potentials, issues, codevelopment, collaboration

\begin{abstract}
RÉSUMÉ
Les projets d'aménagement durable et de conservation (ADC) des ressources naturelles en collaboration avec les peuples autochtones ayant recours à une approche en génomique sont en émergence. Les informations et applications issues de la génomique peuvent leur être utiles, particulièrement dans un contexte de changements climatiques. Toutefois, le défi de transposer ces applications dans la pratique et de les mettre au service des communautés demeure. Nous présentons ici une revue de littérature exploratoire qui aborde (1) les utilités démontrées de la génomique dans les projets d'ADC impliquant les peuples autochtones, (2) certains enjeux qui peuvent limiter l'adoption des applications de la génomique et (3) le travail collaboratif entre chercheurs et communautés autochtones dans les études analysées. Les utilités démontrées identifiées ont été essentiellement de nature socioécologique. La nature complémentaire des savoirs autochtones et des savoirs scientifiques en génomique a été reconnue comme une opportunité qui devrait être développée davantage pour relever les défis actuels, tels que les changements climatiques. En ce qui concerne l'adoption de cette technologie en $\mathrm{ADC}$ dans la pratique, en plus de faire face à des enjeux similaires à d'autres utilisateurs finaux, l'intégration des besoins, des valeurs traditionnelles et des connaissances des communautés autochtones dans les projets de génomique représente également un défi dans un contexte de décolonisation de la recherche en génomique. Finalement, la collaboration communauté-chercheur a été identifiée comme un élément clé pour favoriser la réussite de la transposition de la génomique en ADC.
\end{abstract}

Mots-clés : peuples autochtones, aménagement forestier et faunique, applications génomiques, génétique, adaptation, potentiels, enjeux, codéveloppement, collaboration

\section{E TAKUAPEKESHT}

$\mathrm{Ne}$ atusseun tshetshi minu nakutuenitan assi (ADC) mak innuat ka nanatuapitsheshit ka pishashinit mak e ishipimutemikunin e inniuimikuan tshekuanu uitshi-atussemituat. Atusseuakan ka nanatuapitshanunut apitin, anu ma ume minat e mishkutshipin tshishuk. Mishkuat, e aiatikinikau ne atusseuakan ekuat nete e animimipan. Tan tshipa tshi minu-apitin ne ka nanatuapitsheshit ka pishashinit mak e ishipimutemikunin e inniuimikuan nete innu-assit. Nananitussenitakanipan tan tshipa tshi itapishtanun ne atusseuakan nete innu-assit, nenu innu e ishi katshitaukuat mak nikashkakuat tshetshi mishituepanitat utatusseun mak e tshe ishi uitshi-atussemakanitau innu-assia. Nete tshipa minu-apitin assi e uauitakan miam mate minashkuau,aueshishat e ishi iniutau, nipia, nete kassinu tshekuan assit ka utshipin. Ne innu unishtuapatamun, utshissenitamun kie upukutauan ekuan ne ishi unipinipan kie tshipa minaut minu-apishtakan. Kie peikuit ne tshekuan ishi tshishpeuatakanu,kie ishpitenitakuanu, ne innu ua apishtat kie utissenitiminau nete e nanatuapitshanut ka pishashinit mak e ishipimutemikunin ka inniuimikuan nikapinu ne ua atusset ADC. Nishtuapamakanu anitshenat innu-assi mak ka nanatuapatsheshit takut tshi uitshi-atussemitit tshetshi minupan ne ua pitukutakan ne atusseuakan.

Aimuna: innu, minashkuaua mak aueshishat, atusseuakan ka nanatuapitshanut, e ishi ashu minitunanut,tshe ishi tshiuekapunanut, e ishi pukutakan, e ishi tshishpeuatakan assi, mamu e mishituepinitakan, uitshi-atussemitun.

\footnotetext{
${ }_{1}^{1}$ Département des sciences du bois et de la forêt, Faculté de foresterie, de géographie et de géomatique, Université Laval, 2405 rue de la Terrasse, Québec, QC, Canada, G1V 0A6

${ }^{2}$ Natural Resources Canada, Canadian Forest Service, 1055 Du PEPS, Québec, QC, Canada G1V 4C7 *Corrisponding author: nathalie.isabel@NRCan-RNCan.gc.ca

${ }^{3}$ Chaire de leadership en enseignement en foresterie autochtone, Université Laval, 2405 rue de la Terrasse, Québec, QC, Canada, G1V 0A6
} 


\section{Introduction}

Research in forest and conservation genomics ${ }^{1}$ focuses on the development of new decision-making assistance tools for forest managers, practitioners and decision-makers (Porth et al. 2015; Funk et al. 2019; Isabel et al. 2019; Bernos et al. 2020), including those in Indigenous communities ${ }^{2}$. However, the challenge of transferring research results to these potential users persists (Holderegger et al. 2019). There is still a gap between technologies developed by research on the one hand, and their application and the demonstration of their effectiveness on the other hand for the sustainable management and conservation (SMC) of natural resources (Shafer et al. 2015). Forest and wildlife SMC projects in collaboration with Indigenous Peoples using a genomics approach are growing in number and remain relatively undocumented (Collier-Robinson et al. 2019). In the beginning, the purpose of genomics projects that included Indigenous communities was to document the ancient movements of human populations around the globe and to better understand how certain regions were populated by their first occupants, e.g., South America, the Southwest Region of the Pacific and the Northwest Coast of North America (Homburger et al. 2015; Skoglund et al. 2016; Lindo et al. 2017). However, genomics projects conducted to date with Indigenous communities have been mainly in the area of health and biobanking (Kowal et al. 2012; McWhirter et al. 2015; Baynam et al. 2017; Henare et al. 2019; Morgan et al. 2019). These health projects have contributed to the thinking about legal and ethical issues (Finogentova et al. 2020) such as the protection, access to, and sharing of data (Garrison et al. 2019a), the approach used by researchers engaged in collaborative research (Claw et al. 2018), as well as the recognition of Indigenous rights (Hudson et al. 2020). However, the history of health research has made Indigenous communities hesitant to take part in new genomics projects, given the many ethical issues and lack of respect for Indigenous culture and knowledge (Arbour and Cook 2006; Claw et al. 2018; Garrison et al. 2019b).

Under articles 3 and 4 of the United Nations Declaration on the Rights of Indigenous Peoples (UN 2007), Indigenous Peoples in Canada and elsewhere in the world have the right to self-determination. In exercising this right, they have "the right to autonomy or self-government in matters relating to their internal and local affairs [...]". Within the context of climate change, Indigenous Peoples aspire to greater autonomy in land management and conservation while ensuring that their Indigenous rights are taken into consideration (Martin and Girard 2009). This situation stems from the fact that their cultures, values and ways of life are intimately linked to the land they have occupied and used for thousands of years

\footnotetext{
${ }^{1}$ In this article, the term genomics will be used for both genetics and genomics in order to streamline the text. Genomics is a branch of genetics that studies all of an individual's genes and their interactions.

2"Indigenous Peoples is a collective name for the original peoples of North America and their descendants. The Canadian Constitution recognizes three groups of Indigenous Peoples: Indians (more commonly referred to as First Nations), Inuit and Métis. These are three distinct peoples with unique histories, languages, cultural practices and spiritual beliefs." (Crown-Indigenous Relations and Northern Affairs Canada 2020).
}

(Martin and Girard 2009). Consequently, ecosystem services associated with forests are of paramount importance to them (Martin and Girard 2009; Asselin 2015; Sangha et al. 2018). Thus, just as it impacts ecosystems (Allen et al. 2010; HoeghGuldberg and Bruno 2010; Cardinale et al. 2012; Nelson et al. 2013; GIEC 2014), climate change also affects Indigenous communities in several ways: i) the biophysical environment (Nickels et al. 2005; Gearheard et al. 2010; Golden et al. 2015); ii) the practice of cultural activities such as hunting (Ostapchuk et al. 2012; Abu and Reed 2018), fishing (Downing and Cuerrier 2011) and berry picking (Abu et Reed 2018; Anderson et al. 2018); iii) the ability to travel within the territory (Golden et al. 2015); iv) the transmission of ancestral knowledge from one generation to the next (Downing and Cuerrier 2011); and, v) food security (Furgal et al. 2002; King and Furgal 2014; Rosol et al. 2016). For all these reasons, Indigenous Peoples are demanding, at the very least, a real and upstream participation in the decision-making processes concerning natural resources and their sustainable development in the territories they occupy (Dalton 2006; Wyatt 2008; Schmidt and Peterson 2009; Girard and Brisson 2014; Beaudoin et al. 2015). Their ultimate goal, however, is decisionmaking autonomy.

Within the context of climate change, it is therefore necessary to ensure the resilience of forest ecosystems and to determine their adaptation capacity and their vulnerability in order to adjust SMC measures to new climate realities. This need to adapt implies having access to precise and useful information, and this is where genomics information can be of service. In order to facilitate decisions regarding land development and protection, knowledge of the tools and information available, such as those developed in genomics, will enable Indigenous communities to better target their needs and identify possible solutions and actions to address natural resource management and conservation issues.

\section{Background}

Genomics, used within the context of SMC, can provide solutions to issues that are ecological (Sederoff et al. 2009; Sork et al. 2013), social (Bernatchez et al. 2017) and economic in nature (Porth et al. 2015, 2016; Chamberland et al. 2020). Genomics can also provide an overview of the genetic diversity that exists within a species and the degree of connectivity between populations (Borrell et al. 2019; Godbout et al. 2019; Ingvarsson et al. 2019). It can give us information on a forest species, namely its vulnerability to climate change and its ability to adapt (genetic and phenological diversity) to new environments (Cullingham et al. 2018; Godbout et al. 2019). The genomics information and indicators developed can thus be used to measure the impact of infrastructure development and implementation on populations by measuring and comparing their genetic diversity (Balkenhol et al. 2009; Fauvelot et al. 2009; Jackson and Fahrig 2011; Torterotot et al. 2014). The genomics information collected can also help to refine the development of natural and wildlife resources by outlining, for example, management areas that take into account genetic diversity, the connectivity of populations and the ecological characteristics of the area (Yannic et al. 2016; Mahony et al. 2019; Degner 2020). In SMC projects, this information can lead decision-makers and forest managers to take actions that consider areas of high species genetic diversity and pro- 
jections of species range shifts in response to climate change for conservation or to guide reforestation programs (Nadeau et al. 2015; Borrell et al. 2019). Genomics can also contribute to the restoration of species that are important to local communities such as the American chestnut (Westbrook et al. 2019). The information stemming from genomics can also be integrated into forest bio-surveillance programs (Roe et al. 2019) or into the selection of individuals and the genetic improvement of trees (Porth et al. 2016; Lenz et al. 2019). Genomics is a quick and efficient means of generating powerful information and applications for the conservation of species and the sustainable development of forests (Shafer $e t$ al. 2015; Funk et al. 2018). Currently in SMC, translational research in genomics is in its infancy. That is why, for the purpose of this article, genomics information and genomics tools were considered inseparable.

SMC projects involving the territories and resources of Indigenous communities pose new challenges to researchers in genomics and in land development and conservation, given that they were not initially trained in the social sciences and find themselves faced with research approaches that require more consideration in terms of ethical obligations. In the past, the lack of interaction between researchers and communities gave rise to power struggles that resulted in reduced access to data and benefits for the communities (Smith 1999; Wyatt et al. 2015). This type of situation was observed many times in genomics health studies (TallBear 2013a). Indigenous Peoples were once just perceived as a topic of study (Smith 1999). Deep-seated colonial tendencies in research with Indigenous communities have been criticized and condemned (Smith 1999). Over the last twenty years, efforts have been made to decolonize research and encourage researchers to adopt an approach based on ethical principles (Asselin and Basile 2018). Smith (1999) defines research decolonization as a process by which "Indigenous Peoples want to tell [their] own stories, write [their] own versions, in [their] own way, for [their] own purposes." This trend is part of the quest initiated by Indigenous Peoples for self-determination (Smith 1999). The process of decolonizing research requires a collective awareness of colonialist behaviours that are anchored consciously or unconsciously in non-Indigenous researchers and a deconstruction of this colonial influence in research (McGregor 2018). According to Zavala (2013), one of the strategies that encourages research decolonization is to allow Indigenous Peoples' voices to be heard and for them to increasingly take their rightful place. According to Datta (2018), this process can be initiated by developing a research approach based on ethical principles and relationships. This trend in research decolonization has promoted an expansion in Indigenous research, i.e., research conducted for and by Indigenous Peoples, thereby acknowledging Indigenous knowledge, visions and methodologies (Kovach 2009; McGregor 2018), as well as recognizing and maintaining Indigenous identity, culture, values and languages (Battiste 2000).

Over time and with the shift in researchers' positions toward a decolonization of research (Smith 1999), a dynamic of knowledge co-construction and co-production is beginning to establish itself (Lévesque et al. 2013; Schuttenberg and Guth 2015). At the heart of concerns are: 1) control at every step of the research; 2) access to data; 3 ) sharing of benefits; and, 4) knowledge recognition (Assembly of the First Nations of Quebec and Labrador 2014). By taking into account existing analysis frameworks regarding citizen and Indigenous participation (Arnstein 1969; Wyatt 2008; Beaudoin et al. 2015), collaboration between researchers and communities can take various forms. Thus, the spectrum of community participation and collaboration in research ranges from the exclusion of communities, to consultation, collaboration and co-development, and finally leading to research conducted entirely by Indigenous Peoples (Wyatt 2008). Collaboration includes the integration of Indigenous values and knowledge, the participation of communities in the decisionmaking process and the sharing of responsibilities (Assembly of the First Nations of Quebec and Labrador 2014).

\section{Objectives of the study}

The purpose of this exploratory study was to examine the proven usefulness of information and genomics tools for the SMC of forest and wildlife resources in projects involving Indigenous Peoples, the issues that limit their implementation and adoption into practice in Indigenous communities and the collaborative work between researchers and communities.

\section{Methodology}

A body of 29 documents was established following a documentary search. Given the small sampling of articles found, our study was of an exploratory nature. We completed a literature search to answer the following research question: What are the demonstrated uses and challenges of genomics in sustainable management and natural resource conservation projects with Indigenous communities? The documentary search allowed us to identify peer-reviewed articles. We also took into account, to a lesser extent, student theses and government reports to guide our study, since the subject being studied is relatively recent. The keywords selected for the documentary search reflected three major concepts linked to the research question: 1) Indigenous Peoples; 2) forestry, conservation and wildlife genomics/genetics; and, 3) sustainable management, sustainable forest management, conservation $(\mathrm{S} 1)^{3}$. We used the Boolean operators "AND" and "OR" to combine keywords as well as truncation (i.e., the use of ${ }^{*}$ ) to generate a larger array of results. The searches were conducted between May 27, 2020 and June 24, 2020. Relevant literature published between 1900 and June 2020 was extracted from three online databases, i.e., Web of Science, GeoBase and CAB Abstracts. These databases were initially selected for their complementary nature, making it possible to group together a large array of articles on interdisciplinary environmental studies. No geographic restrictions were imposed and English and French publications were considered.

A two-phased selection process based on a methodology developed by Berrang-Ford et al. (2011), was used to select the publications (Fig. 1). The first selection phase consisted in choosing the relevant publications, based on the title and abstract, from among all the articles initially identified by the literature search $(\mathrm{N}=5383$, including 1091 duplicates $)$.

${ }^{3}$ S1 See supplemental documentation file "supplementary_material.docx" 
Records retrieved from databases $=5383$

Web of Science $=2133$

GeoBase $=663$

CAB Abstracts $=2587$
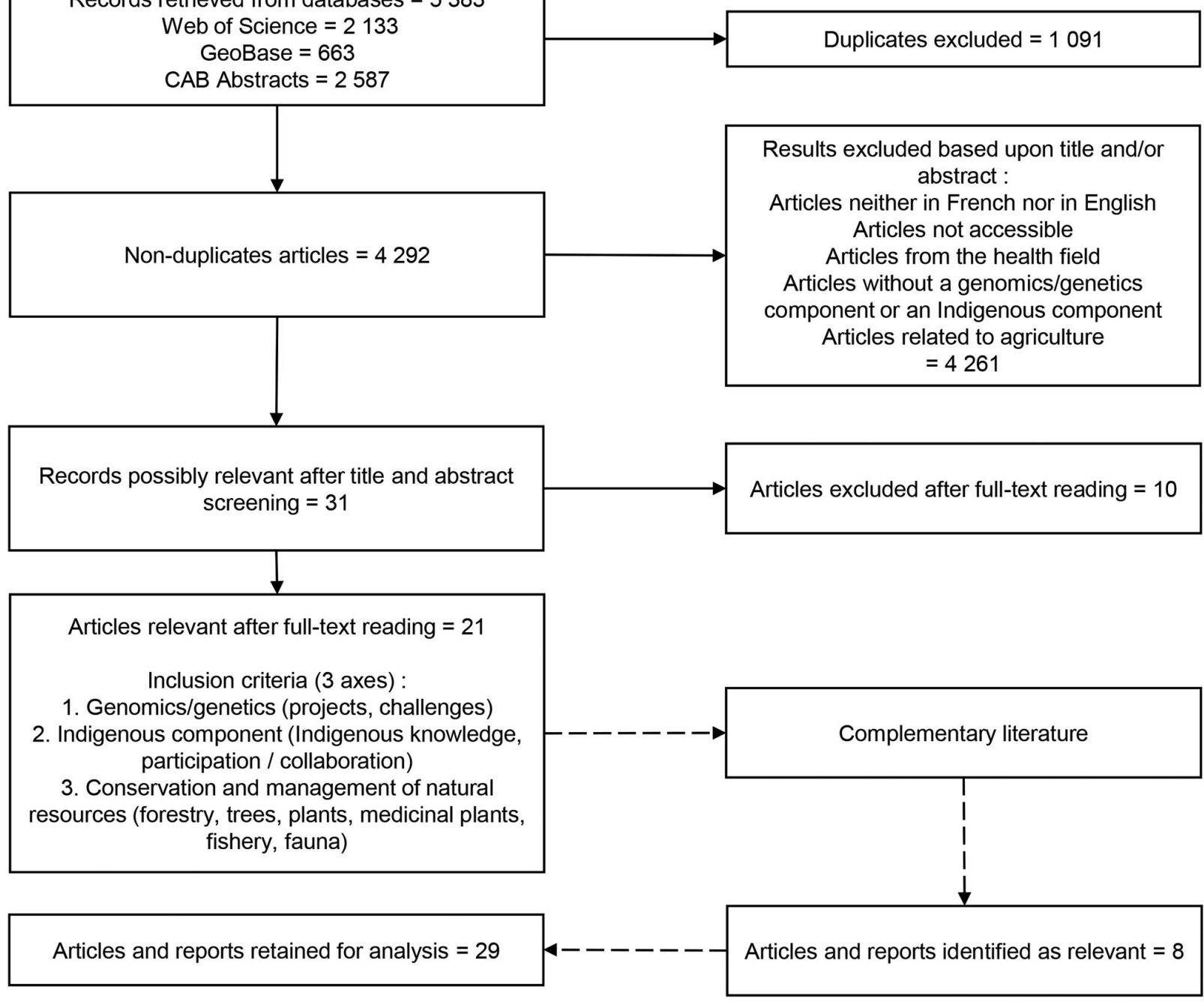

Fig. 1 Summary of the literature search process and the selection of documents analyzed in the data

Thirty-one articles were selected at this stage, whereas 4264 articles that did not satisfy the selection criteria were excluded in the first phase of the selection process. The majority of the excluded articles focused on health genomics in association with Indigenous communities or on forestry and wildlife species conservation and management projects involving Indigenous communities that did not have access to genomics information. In the second phase, a rigorous selection process consisted of a full reading of potentially relevant articles $(\mathrm{N}=31)$. Twenty-one publications that met the inclusion criteria were selected at this stage (Fig. 1). We selected articles directly involving Indigenous Peoples, as well as publications in which members of Indigenous communities and non-Indigenous stakeholders participated $(\mathrm{N}=4)$. Lastly, a complementary search of the articles cited in the selected articles and the grey literature was conducted, based on the same inclusion criteria. This search produced another eight documents that had not been originally identified in the databases, for a total of 29 documents (S2) ${ }^{4}$. The entire publication selection process was completed by a single person (i.e., the first author of this article) as in the methodology in Sanchez Badini et al. (2018).

For each article selected during the literature search, the information pertaining to the proven usefulness and issues of genomics/genetics for Indigenous Peoples in environmental projects was extracted. The NVivo software (QSR International Pty Ltd.) was used to complete a thematic analysis of the selected studies (Thomas and Harden 2008) based on the following two initial nodes: the potential of genomics (proven usefulness to date) for SMC projects involving Indigenous communities and the issues associated with its

${ }^{4}$ S2 See supplemental documentation file "supplementary_material.docx" 
use. An inductive and iterative approach was selected (Creswell 2014) in order to identify sub-nodes (sub-themes) from the initial nodes, thereby making it possible to identify new or recurring themes addressed in the data. The inductive and iterative thematic analysis made it possible to identify three main themes (proven usefulness, issues and collaboration) which were broken down into eight key sub-themes. Although the keyword search did not directly include the theme of collaboration, this theme was recurrent in the articles selected. Although the information collected provided a fragmentary picture of collaboration between researchers and Indigenous communities in SMC projects using genomics, this element remains a relevant one that should be addressed. Similarly, the inductive and iterative analysis revealed two documents on the use of genomics for economic purposes in SMC, a theme that was not initially found in the keywords.

\section{Results}

Proven usefulness

Based on the documents analyzed, the usefulness of genomics in SMC projects involving Indigenous communities can be grouped into three major categories: 1) biodiversity management and conservation; 2) the complementary nature of Indigenous knowledge and scientific knowledge; and, 3) economic potential.

\section{Biodiversity management and conservation ( $n=15$ ) Species of cultural importance}

For Indigenous communities, genomics can provide information that can be integrated into the SMC of culturally important species, including species that ensure food security for certain communities (traditional food) and species of commercial importance such as kēkēwai, a type of crayfish (Collier-Robinson et al. 2019). For example, genetics made it possible to gain a broad picture of the genetic diversity of culturally important species such as caribou in northwest Canada and lake trout in Lake Mistassini (Polfus et al. 2016; Marin et al. 2017). Furthermore, genomics, combined with the knowledge of the Heiltsuk First Nation, made it possible to observe the decline in the grizzly bear population in a conservation zone of the Koeye watershed in British Columbia (Housty et al. 2014). In this study, using a non-invasive sampling of grizzly bear hairs, genomics made it possible to determine the number of individuals present on the territory being studied. The information on the status of the population contributed to the implementation of grizzly bear conservation measures consistent with the principles and values of the Heiltsuk First Nation (Housty et al. 2014). The use of genomics also made it possible to monitor rainbow trout populations in Lake Mistassini (Fraser et al. 2013) where the Cree fish for rainbow trout for subsistence and recreational purposes. This kind of monitoring made it possible to identify populations that are more stable and those likely to be in decline (Fraser et al. 2013). An additional application of genomics consisted in the study of the migratory patterns of rainbow trout, providing a better understanding of what has shaped their genetic diversity and putting in place a conservation plan for this culturally important species (Fraser et al. 2006). In Nunavik, genomics was used to differentiate beluga populations in order to improve the management of these whale populations by Inuit and government authorities, as well as to prevent the over-exploitation of belugas by Inuit hunters (Smith 2000). Lastly, in Mexico, genomics made it possible to study the impact of cacti population (Stenocereus stellatus) management by Indigenous communities on its genetic diversity (Casas et al. 2006). The results of this study highlighted a greater genetic diversity in populations managed by Indigenous communities compared to unmanaged populations. This information was incorporated into a decision support tool with the intent of maintaining genetic diversity in the cacti populations, both wild and managed ones (Casas et al. 2006).

\section{Biogeography, genetic diversity and adaptability}

For Indigenous communities, genomics allows the study of the dispersion factors of a species within its distribution area. Human and natural factors have impacted the dispersion of common camas (Camassia quamash), a species of edible plant used by Indigenous Peoples in Western North America (Tomimatsu et al. 2009). In this case, genomics made it possible to understand the plant's biogeography, but also to disprove the hypothesis of its dispersion by Indigenous Peoples (Tomimatsu et al. 2009). In Australia, genomics, combined with linguistic and anthropological data, helped confirm the dispersion of the Australian boab and the Australian chestnut through Indigenous actions (Rangan et al. 2015; Rossetto et al. 2017). The knowledge of factors (e.g. human action, natural barriers, etc.) that influence the dispersion patterns of a species over a territory is an asset in guiding conservation efforts in a given region and for promoting the implementation of management and conservation strategies (Rossetto et al. 2017).

To better prepare for climate change, genomics can be used to study the vulnerability and adaptability of individuals and populations of plant or animal species to a changing climate and to different environmental conditions. Indeed, the Māori of New Zealand used an approach combining genomics and Māori principles such as whakapapa, whanaungatanga (relationships), manaakitanga (respect), tikanga (method), tohungatanga (expertise), rangatiratanga and kaitiakitanga (stewardship) to study the adaptability of two culturally significant and threatened native aquatic species, i.e. the kōwaro (Canterbury Mudfish; Neochanna burrowsius) and the kēkēwai (crayfish; Paranephrops zealandicus), with the goal of identifying individuals and populations that demonstrate the greatest resilience (CollierRobinson et al. 2019). The information garnered from this picture made it possible to put into place the most appropriate and consistent measures using the principles and values of the Māori (Collier-Robinson et al. 2019). Furthermore, the study of intraspecific genetic diversity using genomics identified individuals that exhibit local adaptation to extreme climate events (Kadykalo et al. 2020), the occurrence of which is likely to be more and more intense in the years to come.

\section{Indigenous knowledge and complementarity with scientific knowledge $(n=10)$}

Some case studies used an approach that promoted the integration of Indigenous and scientific knowledge in genomics (Zuercher et al. 2003; Fraser et al. 2006; Ragupathy et al. 2009; Newmaster and Ragupathy 2010; Rangan et al. 2015; Polfus 
et al. 2016; Marin et al. 2017; Polfus et al. 2017; Rossetto et al. 2017), which made it possible to highlight their complementarity within SMC projects. The two types of knowledge often rely on different temporal periods and spatial scales, but they provide information that is both relevant and complementary (Fraser et al. 2006). Indigenous knowledge, for example, provides finer-scale, point-in-time information for targeted areas of a territory (Fraser et al. 2006; Polfus et al. 2016; Marin et al. 2017) while genomics-derived data provides a larger-scale picture (Fraser et al. 2006; Polfus et al. 2016). Benefits have been derived to date from the complementarity between Indigenous and scientific knowledge, including contributing to a holistic explanation of complex systems such as migration patterns and genetic diversity of aquatic species in Lake Mistassini (Fraser et al. 2006; Marin et al. 2017), or to a better understanding of the ecology and population variation of a species such as caribou (Polfus et al. 2016). Furthermore, Indigenous knowledge has been used to refine the taxonomy of plant species that was previously based on scientific knowledge (Ragupathy et al. 2009).

In Australia, two studies used genomics and linguistic data (e.g., traditional songs) that turned out to be useful sources of information in order to build a complete picture of the dispersion of the Australian boab and Australian chestnut, two culturally important species, thereby gaining a greater understanding of the dynamics between Indigenous communities and these tree species (Rangan et al. 2015; Rossetto et al. 2017). Indigenous Peoples have been identified as having an impact on the current distribution range of these two species by acting as a dispersion vector over time, thereby promoting gene flow, despite the presence of biogeographic barriers (Rangan et al. 2015; Rossetto et al. 2017).

Indigenous knowledge provides qualitative data that have been used to establish characteristics and criteria for identifying species or distinguishing between populations within the same species (Polfus et al. 2016; Marin et al. 2017). For example, the results from the genomics approach used by Polfus et al. (2016) for caribou helped identify three separate genetic groups. These groups were then corroborated by Dene knowledge. A group of hunters was able to differentiate the caribou populations into groups similar to those established by scientific data (Polfus et al. 2016). The combination of genomics and Indigenous knowledge of species of cultural importance has highlighted the evolutionary history of the caribou, promoting a better understanding of current population structures (genetic diversity and connectivity) (Polfus et al. 2016).

Incorporation of Indigenous knowledge can also be seen as an opportunity for sharing with members of Indigenous communities involved in a project and build trust, in addition to representing an additional opportunity to explain the benefits of a project (Marin et al. 2017). Seizing the opportunity to be in direct contact with community members on the territory created an opportunity for Indigenous knowledge sharing in the form of frequent exchanges between researchers and Indigenous Peoples, making the process of collecting Indigenous knowledge more natural (Marin et al. 2017).

\section{Economic potentials $(n=2)$}

Although the theme of economics was not initially a keyword in the literature search, two documents taken from the study data addressed the use of genomics for economic purposes.
These two studies conducted in Canada, one in British Columbia and the other in Quebec, focused on the use of marker-assisted selection (MAS) in the genetic improvement of commercial forest species, including white spruce. MAS, in a context of increasing forest productivity, can be considered as an application of genomics with economic potential for commercial species breeding programs used to shorten selection times. The information from MAS represents an indirect economic potential for Indigenous communities who could benefit from selected varieties by planting them on their lands. In both studies, the emphasis was placed on the perception of potential MAS users, including Indigenous communities (Maltais 2010; Nilausen et al. 2016). However, MAS has not received unanimous support from Indigenous communities and their opinion of its potential for both research and implementation is mixed (Maltais 2010; Nilausen et al. 2016). Perceptions regarding the use of genomics by Indigenous Peoples will be addressed in the following section on issues likely to impede the adoption of genomics in SMC projects.

A significant advantage of genomics, which did not fall into the three main categories above, is the fact that sampling is non-invasive (Housty et al. 2014) and minimally harmful to the individuals sampled (Fraser et al. 2006). Such sampling is more in line with the principles and values of Indigenous communities, including those of the Heiltsuk First Nation for whom respect of other living things is paramount, as is limiting the impact of human activity on the study area, and the living beings found there, including the impacts of research activities (Housty et al. 2014).

\section{Challenges}

While the studies analyzed revealed many demonstrated uses of genomics in SMC projects for Indigenous communities, other observations stemming from the thematic analysis of the data focused on issues that may impede the adoption into practice of genomics tools and information. Among the issues identified, some are more related to Indigenous reality whereas others are shared by the majority of the end users.

\section{Challenges associated with Indigenous reality Research ethics and communication ( $n=10$ )}

The studies analyzed made it possible to identify a few avenues of reflection on ethical issues in natural resource SMC genomics projects in collaboration with Indigenous communities. Some articles reported that past behaviours of researchers, particularly in the health field, may contribute to a reluctance on the part of Indigenous community members to trust again and participate in genomics projects (Percy et al. 2010; Geary et al. 2013; Nilausen et al. 2016). In fact, Geary et al. (2013) mentioned that the use of data for purposes other than those planned or the sampling of data without the consent of the involved Indigenous communities contributed to creating a climate of mistrust. This also seems to be tainting current research in genomics, even within a context of the SMC of natural resources (Collier-Robinson et al. 2019). The importance of involving communities in all steps of the project, sharing control of the research and obtaining free, prior and informed consent are the foundations for an ethical Indigenous research approach (Geary et al. 2013).

Communication prior to genomics projects was also 
identified as an obstacle by Collier-Robinson et al. (2019) and by Kadykalo et al. (2020). In order for Indigenous communities to make an informed decision about whether or not to participate in research or use genomic information in the future, Collier-Robinson et al. (2019) suggest that the risks and benefits of potential approaches be clearly stated. Poor communication of risks and benefits prior to and during the project could affect the openness of communities to the technology and make them less likely to use it in the future (Kadykalo et al. 2020).

The use of outreach tools could be an avenue for communicating genomics information to communities (Touchette 2020). In fact, Touchette (2020) used the preparation and presentation of concrete case examples, in the form of a PowerPoint presentation, to present some of the potential applications of genomics for the SMC of forest and wildlife resources within the context of climate change. Three case examples, based on interest, culture and the activities of the targeted Indigenous community, were selected. In order to present a logical sequence in the demonstration of the use of genomics data, the case examples were developed to illustrate a gradation in the use of data, going from a local (e.g., genetic diversity of a fish species in a river after the installation of culverts), territorial scale (e.g., distribution of caribou ecotypes based on ecological zones), to a North American scale (e.g., distribution range of white pine in relation to climate adaptation). Thus, in addition to presenting the context of the study and the main findings from a genomics approach, for all cases, a link was established between what genomics can provide as information (e.g. genetic diversity and population connectivity within a species) and how this information can be used concretely for SMC.

The communication issue can also manifest itself in a lack of interaction and follow-up on the part of researchers with the communities involved, often after sample collection has occurred (Geary et al. 2013). These authors, as well as CollierRobinson et al. (2019), report that Indigenous Peoples have been impacted when researchers have neglected to make the necessary efforts to return to them to share their research findings and make them concrete and accessible to the communities involved. Throughout a research project, communities should ideally be kept informed of the project's progress, the approaches chosen, and their benefits and inconveniences, as well as initial results (Polfus et al. 2016).

The presentation of research results in layman's terms is another communication issue that genomics researchers must contend with (Polfus et al. 2017). This issue can be seen as an opportunity to share the approach and results of the project, not only with the people who are closely involved in the project, but also for the general public and with young people who are the future users (Polfus et al. 2016). Polfus et al. (2017) used art to communicate the research in a novel way with Indigenous communities and to facilitate exchanges and initiate discussions. Art made it possible to communicate genomics concepts in layman's terms and facilitate their understanding (Polfus et al. 2017). The presence of a cartoonist at certain meetings made it possible to use the ninth art to allow everyone, both researchers and community members, to be on the same page with regard to the information and concepts shared by both sides (Polfus et al. 2017). Lastly, the lack of recognition by scientists of
Indigenous Peoples and their knowledge was raised, depriving communities of their fair share of the credit and benefits (Geary et al. 2013). More and more research on medicinal plants combines traditional knowledge with scientific knowledge (genetics and genomics) and has a commercialization objective (Geary et al. 2013). Within this specific context, researchers and businesses have been imposed a national legal framework that guides the management of data accessibility in addition to making sure that there is a just, fair and equitable return and sharing of benefits with the communities involved (Geary et al. 2013). Indeed, the Nagoya Protocol, adopted in 2010, has fueled collective awareness of the importance of recognizing Indigenous Peoples' rights to genetic resources and traditional knowledge and ensuring the appropriateness of the purposes for which they are used (Geary et al. 2013). Safety, accessibility and the use of data are at the core of ethical considerations (CollierRobinson et al. 2019).

\section{Integration of Indigenous knowledge $(n=4)$}

While Indigenous knowledge and genomics science have proven to be complementary, an approach integrating Indigenous knowledge into genomics projects poses certain challenges. In fact, Indigenous knowledge provides a large quantity of qualitative and timely information at a spatial and temporal scale that is different from that provided by genomics (Fraser et al. 2006). One of the first issues encountered was choosing the most appropriate method for collecting Indigenous knowledge (Fraser et al. 2006). In the study by Fraser et al. (2006), three complementary methods were used to gather knowledge: discussion groups, semi-directed interviews and discussions with members of the community out in the field. To obtain as much information as possible appropriate to the context of the study, the identification and selection of key information providers, in this case fishers from the Cree community of Mistassini, played an important role in data acquisition (Fraser et al. 2006). A second issue potentially facing researchers is language comprehension. The information providers speaking Indigenous languages require the presence of an interpreter to understand the subtlety of the language and terms used which do not always have an English equivalent (Fraser et al. 2006; Marin et al. 2017). Furthermore, the process of collecting and understanding Indigenous knowledge can lengthen the research timeframe. For example, in the case of Fraser et al. (2006), the process required multiple meetings of 3 to 5 hours, spread out over a few years, with key stakeholders from the community. Data processing and the organization of knowledge also requires turning them into information that can be used in practice to inform decision-making (Fraser et al. 2006).

\section{Challenges shared by all end users \\ Perception ( $\mathrm{n}=4)$}

Our literature review revealed a few articles addressing the perception of genomics within the context of the SMC of natural resources by Indigenous Peoples. The perception of genomics information and applications by members of Indigenous communities seems to vary based on the context in which the information is used and their level of understanding regarding genomics (Nilausen et al. 2016; Touchette 2020). It would seem that the perception of genomics is more 
favourable in a context of conservation or restoration (Nilausen et al. 2016; Touchette 2020), as was observed in other systems (e.g. Westbrook et al. 2019). In the eyes of end users, genomics is often perceived as something obscure due to a lack of understanding, information, and explanation of its resulting uses by genomics researchers (Kadykalo et al. 2020). Maltais (2010) and Nilausen et al. (2016) found that First Nations had a negative first impression of markerassisted selection (MAS) within the context of genetic improvement and increased wood fibre production. Furthermore, Nilausen et al. (2016) reported that members of First Nations had a negative and contextually variable perception of both the use of MAS and the general use of genomics tools in the forests of British Columbia. In Quebec, Maltais (2010) mentioned that the perception of Indigenous Peoples regarding the use of MAS in research is mixed, while its concrete application in Quebec forests is seen more negatively. Genomics has often been mistaken for genetic engineering and genetically modified organisms (GMOs) (Nilausen et al. 2016; Touchette 2020). This field of research was also seen in a more limited or "single-use" context (e.g., associated with genetic improvement), with communities not perceiving the wide range of potential of genomics (Touchette 2020). This interpretation of genomics being associated with GMOs can have a negative impact on the adoption into practice of genomics tools and indicators by Indigenous Peoples. The perception of genomics is also affected by past relationships between Indigenous Peoples, the government, researchers and the forest industry (Nilausen et al. 2016). However, the perception of genomics can evolve over time by demystifying genomics and providing additional explanations of its potential, risks and benefits (Kadykalo et al. 2020; Touchette 2020). Within the fisheries context, practitioners, including Indigenous communities, have perceived the usefulness of genomic information, tools and research, as relevant new information to incorporate into decision-making involving the conservation of aquatic species, even though they initially had little knowledge of genomics (Kadykalo et al. 2020). Indigenous managers also saw genomics information as an additional tool in their toolbox to facilitate decision-making (Kadykalo et al. 2020; Touchette 2020).

\section{Transposition into practice $(\mathrm{n}=4)$}

Transposition to end users can come with certain challenges since genomics is a relatively new field, as are its practical applications (Kadykalo et al. 2020). As proof, a survey of Indigenous and non-Indigenous practitioners revealed that nearly $75 \%$ of respondents had very little knowledge of genomics concepts (Kadykalo et al. 2020). This lack of understanding can lead to the inappropriate use of technologies and information made available to managers and a more limited acknowledgement of the limits of genomics information in response to a specific need or a specific question (Kadykalo et al. 2020). In addition, a limited understanding can lead to the possibility of sub-optimal use of genomic information and diminish confidence in the applications developed in the field of genomics (Kadykalo et al. 2020). However, this does not seem to prevent stakeholders, after explanations, from considering its use in the future (Kadykalo et al. 2020). In order to improve the level of understanding of the concepts and their applications, Nilausen et al. (2016) proposed devel- oping outreach tools for Indigenous communities and other end users. In order for Indigenous Peoples to benefit, these outreach tools should be neutral and should paint a picture (as complete as possible) of the usefulness, benefits and disadvantages of the available tools and information (Nilausen et al. 2016).

The lack of support and exchange in facilitating an understanding of genomics information are also factors that limit the optimization of their implementation in practice (Crann et al. 2015; Touchette 2020). Crann et al. (2015) reported that a minimum level of understanding among end users must be achieved so that they are able to understand and use genomics information properly. The sheer volume of data generated seems to be an impediment for Indigenous and non-Indigenous practitioners who sometimes have difficulty navigating the data (Kadykalo et al. 2020). Furthermore, the time required for the translational research to develop applications and non-molecular indicators of genetic diversity, as well as put them into practice, is not keeping pace with the actions that should be taken to respond to issues regarding the SMC of natural resources in practice (Kadykalo et al. 2020). The time needed to complete analyses based on collected data must be within a reasonable timeframe (rather short) in order to benefit from the data and use it as a decision-making tool (Crann et al. 2015). Also, for genomics to be recognized by practitioners as a field providing useful information in practice, its applications and non-molecular indicators must not be an additional burden (in relation to other tools being used) for those that use it (Crann et al. 2015). Furthermore, according to Kadykalo et al. (2020), the information provided by genomics-derived data for use in concrete SMC measures must be easy to identify by practitioners. Thus, the effectiveness of genomics and its applications should be demonstrated (Crann et al. 2015). Exchanges (meetings and discussions) between researchers and end users, including Indigenous communities, are important to translate applications and information into practice. Indeed, it is this lack of exchange that is reported by Kadykalo et al. (2020) and this need for increased communication that is stated by Crann et al. (2015). In the same vein, close collaboration between involved community members and researchers, coupled with transparent knowledge sharing, seem to be key elements identified by Crann et al. (2015) in the practical application of genomics information.

\section{Economic issues $(n=3)$}

One of the main considerations stated in the reviewed articles that may hinder the implementation of SMC projects is the cost associated with the use of genomic-based information and the development of non-molecular indicators that may result. In order to be considered by end users, applications must be affordable to be proven in practice (Crann et al. 2015). If this condition of affordability is not respected, users will turn to other management and conservation methods with which they are more familiar and that cost less (Crann et al. 2015). According to Crann et al. (2015), uncertain funding would act as a barrier to the adoption of new technology and would make the communities more "hesitant" to use them. Limited financial resources to address several SMC issues would not be favourable to a significant investment in a single decision-support tool (Kadylalo et al. 2020). Some 
potential users feared that an investment in a decision-support tool such as genomics information would divert money from being invested in concrete SMC actions (Kadykalo et al. 2020). Also, the larger investments at the beginning of the project, the additional unknown costs associated with equipment purchase and capacity development (Nilausen et al. 2016), and the costs of data management, have led to concerns about running out of funds to complete the project (Kadykalo et al. 2020). However, this technology is becoming more and more affordable over time (Crann et al. 2015). In order for end users to be inclined to turn to genomics, they must be able to see tangible benefits to the community, and from an economic standpoint, there must be an apparent return on the investment made (Kadykalo et al. 2020).

\section{Community-researcher collaboration $(n=14)$}

Among the studies selected that address genomics projects applied to the SMC of natural resources and that include an Indigenous component, collaboration is a theme that is often found in the background, although this theme is not among the keywords used in the literature search. Hence, some of the articles showed a greater sensitivity to relational issues. A wide spectrum of collaboration and participation between researchers and Indigenous Peoples was observed from one study to another, ranging from researchers simply informing communities (Casas et al. 2006), to the implementation of a co-development project where Indigenous communities and researchers both participated in the decision-making process (Collier-Robinson et al. 2019).

In some articles, a low level of collaboration taking the form of consultations with the communities involved was identified (Casas et al. 2006; Dupont et al. 2007). Consultations took the form of: i) informing the communities affected by the project, ii) obtaining permission to work and sample in the communities' territory (Casas et al. 2006) or iii) information exchanges and discussions with local experts before researchers began sampling (Dupont et al. 2007). In certain cases, the interactions between researchers and communities were limited to a comparison between traditional knowledge and scientific knowledge (Zuercher et al. 2003; Ragupathy et al. 2009; Newmaster and Ragupathy 2010; Stronen et al. 2014). In other cases, the comparison between the two types of knowledge was surpassed by adopting a more collaborative and participatory approach, allowing the integration of Indigenous ecological knowledge into genomics studies (Fraser et al. 2006; Fraser et al. 2013; Polfus et al. 2016; Marin et al. 2017; Collier-Robinson et al. 2019). Furthermore, one form of collaboration noted was the participation of members of some Indigenous communities in a project to identify sampling sites and in the sampling itself (Fraser et al. 2006; Polfus et al. 2016; Marin et al; 2017; Collier-Robinson et al. 2019).

Some studies called for co-development by using an even closer collaborative approach between Indigenous communities and genomics researchers. This co-development involved incorporating Indigenous values and principles (e.g., Heiltsuk Nation's Gvi'ilas: customary law) that shaped the research and guided decision-making throughout the project (Housty et al. 2014; Collier-Robinson et al. 2019), or by involving the communities in all stages of the project (Polfus et al. 2016; Collier-Robinson et al. 2019). For example, community members were encouraged to participate in a caribou project in the Northwest Territories by attending public meetings to prepare the sampling (Polfus et al. 2016). Polfus et al. (2016) focused on knowledge sharing with the public and young people, thereby building capacity within communities. Researchers encouraged community members, through various media (radio, advertising, newspapers, social media), to get involved in sample collection (Polfus et al. 2016). Researchers also fostered a co-production of knowledge resulting in the identification of findings that integrate both Indigenous principles and knowledge and the science of genomics (Polfus et al. 2016). Discussion groups and an advisory group were set up to optimize researcher-community collaboration. Collaboration has also continued with the community by providing feedback to share project results (Polfus et al. 2016).

One project deserves special attention because of its good collaborative practices. This is the case of Collier-Robinson et al. (2019) who applied the following four key Māori principles to their genomics project involving the SMC of culturally significant species: 1) exercise authority over the knowledge and culture that Mãori wish to share; 2) promote the development of capacities and expertise within communities; 3 ) develop and maintain sustainable and significant relations with researchers; and, 4) promote full Māori responsibility for the environment, species, samples collected, data generated, data access, culture, and knowledge (Collier-Robinson et al. 2019). By recognizing the Māori’s own value and knowledge system, their needs and management objectives and their territorial rights, Collier-Robinson et al. (2019) advocated a form of collaboration that promoted Māori engagement, co-development of knowledge and shared decisionmaking. With this approach, the researchers managed to involve the Māori in the key stages of a genomics project.

Some articles identified challenges related to collaboration. Indeed, mistrust and lack of trust between genomics researchers and communities were seen as obstacles that need to be overcome before a sustainable communityresearcher relationship can be built (Nilausen et al. 2016). Furthermore, Kadykalo et al. (2020) identified that an important phase of collaboration, i.e. returning to share research results with end users, is often neglected. Similarly, making a complete deliverable or application accessible and easy to implement in practice for users has proven to be an additional collaborative challenge (Kadykalo et al. 2020). Although there are some challenges to collaboration, Fraser et al. (2006) suggest that collaboration opportunities that arise in a project are an opportunity to rebuild trust between researchers and the community in addition to creating opportunities to communicate and share the benefits of the project to the community.

\section{Discussion}

The establishment of natural resources SMC projects in genomics is a relatively recent phenomenon, especially those involving Indigenous communities, as reflected by the limited number of articles in our exploratory study. Our study highlighted, through a literature review, the demonstrated usefulness to date of genomics-based approaches that have been employed in SMC projects for forest and wildlife resources involving Indigenous Peoples. It also highlighted challenges that still act as a barrier to Indigenous communi- 
ties in adopting the use of genomics in practice, and that would benefit from further exploration.

Based on the results obtained, we found that the demonstrated uses of genomics in SMC projects with Indigenous communities are largely socio-ecological in nature. Several studies focused on the conservation and management of culturally significant aquatic species. Thus, harnessing genomics to serve Indigenous Peoples in SMC projects seems to primarily involve projects that focus on: 1) land protection, biodiversity conservation and sustainable and integrated resource management, and 2) the complementarity of Indigenous knowledge and scientific in genomics knowledge.

However, although they were not an integral part of the literature search, the almost exclusively economic potentials of genomics in SMC were only minimally addressed in the data and were perceived more negatively by Indigenous Peoples who appear to be more interested in applications that incorporate their values and culture. According to Wyatt (2008), the management paradigms that exist among Indigenous Peoples are distinct from the dominant cultural paradigm in the forestry sector, which are more economic in nature. The economic component deserves to be explored in greater depth through future research.

Furthermore, although the integration of Indigenous knowledge has emerged as a challenge in SMC projects using genomics information, our results highlighted the potential for complementarity between Indigenous knowledge and scientific knowledge in genomics. Indeed, combining Indigenous and scientific knowledge can provide a more complete understanding of the ecosystems and the species within them (including humans), both to explain the past and predict the future, by combining data collected at various socio-temporal scales, which is an asset in the context of climate change (Huntington et al. 2004; Ban et al. 2018). An article based on a three-pronged approach (Indigenous knowledge, genomics and phenotypic traits), however, raised the issue of recognition of Indigenous knowledge by the scientific community (Bowles et al. 2020a; Bowles et al. 2020b). In fact, a critique of the Bowles et al. (2020a) article by Larson et al. (2020) did not take into account Indigenous knowledge that supported the study's conclusion (Bowles et al. 2020b).

In several of the articles analyzed, collaboration between genomics researchers and Indigenous community members emerged as an important element, if not a pillar, in natural resources SMC projects using a genomics approach. This collaboration can take many forms, corresponding to varying degrees of community involvement (Arnstein 1969; Wyatt 2008). Although the portrait of collaboration depicted in our study is fragmentary, the trend observed based on the results indicates an evolution in the collaborative approach favoured over time. The most recent studies in the data show closer collaboration between communities and researchers, integrating values, principles and culture specific to the communities involved, favouring an ethical approach and giving greater recognition to the quest for self-determination of Indigenous Peoples. The combined efforts of communities and researchers have had a leveraging effect, making it possible to deepen the understanding of species and systems studied. Our results point in the same direction as the findings of Ward-Fear et al.'s (2019) study in Australia on lizard populations, for which a collaborative approach between researchers and Indigenous communities was able to positively influence the results and outcome of the research through the union of two visions. Collaboration in this project had a direct impact on the SMC measures recommended for a species of lizard (Ward-Fear et al. 2019). Although the current trend is towards greater community participation in genomics projects, it is up to communities to choose their level of involvement and collaboration, to a greater or lesser extent, in such projects.

Challenges, including the implementation of genomics applications into practice, the lack of understanding of the information and tools, the lack of expertise, the costs of using and analysing data, uncertain funding, and the time required to analyze data were reported in the reviewed body of literature. These issues were also identified as barriers to the practical use of genomics in SMC projects by non-Indigenous practitioners in the Taylor et al. (2017) and Bilodeau et al. (2019) studies. Some of the issues faced by Indigenous communities are also experienced by other end users. It is important to note, however, that it is not a matter of training future specialists who will develop genomics tools, but rather to build capacity within communities so that the individuals responsible for SMC are able to refer to genomics information when needed.

In contrast to the results obtained in the studies by Taylor et al. (2017) and Taft et al. (2020) on non-Indigenous practitioners, the perception of genomics by Indigenous communities still appears to be a barrier to its adoption in practice. The perception of new technology can however evolve over time (Straub 2009). When such a perception is based on limited knowledge, new information and the presentation of concrete examples can help influence and change people's perceptions and opinions (Pardo et al. 2002). The fragmented understanding of genomics that remains in practice and influences the perception and adoption of developed technologies could benefit from a broader range of outreach tools. This fragmentary understanding is consistent with Porth et al. (2015) who state that genomics and its spin-offs are still, unfortunately, poorly understood by end users. However, communication efforts between researchers and practitioners seem to have a positive impact over the short term (Lundmark et al. 2017), and over the longer term (Lundmark et al. 2019), regarding the understanding and perception of genomics concepts. Thus, in order to close the gap between theory and practice, a didactic approach, such as using outreach tools, has been identified as a catalyst to facilitate the adoption of genomics-based technologies (Bilodeau et al. 2019). In this sense, a project entitled Genomics in Society (https://genomics.forestry.ubc.ca/) has been set up at the University of British Columbia to develop educational tools in forestry genomics that will take into account the values and interests of First Nations.

In the data analyzed, one of the issues that often arose was the integration of Indigenous interests, principles, values, culture and knowledge, while respecting ethical principles, so that SMC projects can meet the real needs of communities. Asselin and Basile (2012) mention that an ethical approach to research combined with the implementation of projects that are aligned with the real needs of Indigenous communities, and that generate benefits as well as capacity development in these communities, are the key issues for the success of pro- 
jects with Indigenous communities. Involvement and commitment on the part of researchers in the process of the reconciliation and decolonization of research, as well as openness and sensitivity to Indigenous culture and realities, an often overlooked step, were identified by several researchers as avenues for improving relationships between the scientific community and Indigenous Peoples (Asselin and Basile 2012; McGregor 2018; Bozhkov et al. 2020). According to TallBear (2013a; 2013b), genomics is a field that relies on rather traditional, even colonialist, theoretical principles and definitions. For example, in population genomics there is a tendency to dissociate human populations from their territorial relationships and socio-cultural environment rather than considering them as a whole. In fact, from the very beginning, what defines "being Indigenous" diverges and even goes against how Indigenous Peoples define themselves (TallBear 2013b) (For more details, consult TallBear (2013a; 2013b)). Given the diversity of human-nature relationships (Descola 2005) and the particular relationship/bond Indigenous Peoples have with nature (TwoTrees and Kolan 2016), it is possible to question how the more traditional concepts of the genomics approaches resonate with communities and, more specifically, how they may interfere with Indigenous culture and knowledge. These considerations merit further exploration to paint a more complete picture of the issues that may limit the use of genomics applications and information by Indigenous Peoples.

The ways in which human DNA samples from Indigenous peoples have been handled in the past, as well as the outcomes that have resulted (e.g., whether or not, based on DNA, an individual or group of individuals belonged to an Indigenous community) have left an indelible mark on them (Arbour and Cook 2006; TallBear 2013a), and are likely to taint future forest and wildlife SMC genomics projects with Indigenous Peoples (Collier-Robinson et al. 2019). Several articles addressing ethical considerations in genomics with Indigenous Peoples have been published in the health field and thus were not inventoried and analyzed as part of our study (Arbour and Cook 2006; Claw et al. 2018; Garrison et al. 2019b). What emerges however, is that the ethical approach of researchers should not be limited to that proposed by universities and funding agencies who place more emphasis on the ethics of the research field, i.e. the steps prior to and during the project and not following its completion (Zhang 2017). Yet, an approach that promotes gratitude to the communities involved in the research projects by providing them with services based on their needs (a care approach) should be targeted, since the relationships built during a project will often continue beyond its completion (Zhang 2017).

\section{Conclusion}

The goal of our study was to investigate the proven usefulness and challenges related to the use of genomics in projects involving Indigenous Peoples in the sustainable development and conservation of forest and wildlife resources. The proven benefits of genomics were essentially socio-ecological in nature. The complementary nature of Indigenous knowledge and genomics knowledge also emerged as an interesting potential to be developed. In addition to facing issues similar to other end users, the challenge of integrating the values, needs and knowledge of Indigenous communities into genomics projects is also an obstacle to the adoption into practice of this technology in SMC by Indigenous Peoples. The quality of collaboration was identified as a key element in promoting the successful transposition of genomics in SMC projects with Indigenous communities in most of the articles analyzed.

Our study has certain limitations. The main limitation is the fact that the data used in this exploratory study is composed of a small sample of articles, smaller than what is generally used in a systematic literature review (Paul and Criado 2020). This limitation is attributable to the fact that the subject of the study is an emerging field and few articles simultaneously address genomics, Indigenous Peoples and the SMC of natural resources. The keywords used in the literature search were unable to paint a complete picture of certain themes such as ethics, economics and the relationship between Indigenous communities and genomics researchers in SMC projects that would require further research. Furthermore, even though there were no geographical restrictions regarding the source of the articles selected for the study, we called upon a network of contacts composed mainly of researchers in Canada in order to enhance the study. This has resulted in data containing mostly articles on the situation in Canada, thus biasing the picture painted in this study.

This study was intended to provide answers to the question: How can genomics be used to benefit Indigenous Peoples in SMC projects involving forestry and wildlife resources? One question remains however: "Who" should facilitate the uptake of genomics by Indigenous Peoples? Are the communities the right ball carriers to assume this role or do they need support? Greater involvement and investment by decision-makers and policy-makers in knowledge mobilization and transfer would be a first step. Furthermore, are organizations such as the First Nations of Quebec and Labrador Sustainable Development Institute (FNQLSDI), which is involved with Indigenous communities in forestry, biodiversity conservation, sustainable development of the land and the identification of climate change impacts, the stakeholders that research has forgotten and who could serve as conduits between researchers and communities? Such organizations, already involved with First Nations, know the values and needs of communities in terms of the sustainable development of the land. Relationships developed over time with several communities facilitate communication. That is why these organizations could play an important role in information sharing and outreach, an essential role in raising awareness of genomics applications, their usefulness and their potential for SMC. Furthermore, these organizations could serve as a bridge to facilitate contact between communities and genomics researchers.

\section{Acknowledgements}

We are extremely thankful to Marc St-Onge, Kathleen Goulet and the entire Management Committee of the Innu Essipit First Nations Band Council who helped enhance our discussions and fueled our thought process. We also want to thank Emily Telfer, Heidi Dungey (Scion Limited New Zealand), and Solange Nadeau (NRCan) who opened up new horizons for us, including SMC issues regarding Indigenous communities, as well as Francine Audet and Jean Fontaine for their daily support. We would like to acknowledge the important 
contribution and support of the Chair in Educational Leadership in Indigenous Forestry at Université Laval for all the work done prior to the project. This research was funded by the Natural Sciences and Engineering Research Council of Canada as part of the Undergraduate Student Research Awards program awarded to Lyne Touchette and by the Fonds de recherche du Québec - Nature et technologies as part of the Programme bilatéral de recherche collaborative Québec-Mexique (2018-265002) to Ilga Porth, Jean-Michel Beaudoin, Nancy Gélinas and Nathalie Isabel, and the Initiative R\&D en Génomique to Nathalie Isabel. We thank Carole Coursolle for providing feedback on the English version of the manuscript.

\section{References}

Abu, R. and M. G. Reed. 2018. Adaptation through bricolage: Indigenous responses to long-term social-ecological change in the Saskatchewan River Delta, Canada. The Canadian Geographer 62(4): 437-451. doi: 10.1111/cag.12469.

Allen, C. D., A. K. Macalady, H. Chenchouni, D. Bachelet, N. McDowell, M. Vennetier, T. Kitzberger, A. Rigling and D. D. Breshears. 2010. A global overview of drought and heat-induced tree mortality reveals emerging climate change risks for forests. For. Ecol. Manage. 259(4): 660-684. doi: 10.1016/j.foreco.2009.09.001.

Anderson, D., J. D. Ford, and R. G. Way. 2018. The impacts of climate and social changes on cloudberry (bakeapple) picking: A case study from southeastern Labrador. Hum. Ecol. 46(6): 849-863. doi: 10.1007/s10745-018-0038-3.

Arbour, L. and D. Cook. 2006. DNA on loan: Issues to consider when carrying out genetic research with aboriginal families and communities. Public Health Genomi. 9(3): 153-160. doi: $10.1159 / 000092651$.

Arnstein, S. R. 1969. A ladder of citizen participation. J. Am. Instit. Planners 35(4): 216-224. doi: 10.1080/01944366908977225.

Asselin, H. 2015. Indigenous forest knowledge. In: K. Peh, R. Corlett and Y. Bergeron (Eds.). Routledge Handbook of Forest Ecology. pp. 586-596. Earthscan Routledge, New York, NY. doi: 10.4324/ 9781315818290

Asselin, H. and S. Basile. 2012. Éthique de la recherche avec les peuples autochtones. Qu'en pensent les principaux intéressés? Éthique publique. Revue internationale d'éthique sociétale et gouvernementale. 14(1). doi: 10.4000/ ethiquepublique.959.

Asselin, H. and S. I. Basile. 2018. Concrete ways to decolonize research. ACME: An International Journal or Critical Geographies 17(3): 643-650.

Assemblée des Premières Nations Québec-Labrador. 2014. Protocole de recherche des Premières Nations au Québec et au Labrador. 2nd ed. 110 p. Wendake, Qc.

Balkenhol, N. and L. P. Waits. 2009. Molecular road ecology: Exploring the potential of genetics for investigating transportation impacts on wildlife. Mol. Ecol. 18(20): 4151-4164. doi: 10.1111/ j.1365-294X.2009.04322.X.

Ban, N. C., A. Frid, M. Reid, B. Edgar, D. Shaw and P. Siwallace. 2018. Incorporate Indigenous perspectives for impactful research and effective management. Nature Ecol. Evol. 2(11): 1680-1683. doi: 10.1038/s41559-018-0706-0.

Battiste M. 2000. Maintaining aboriginal identity, languages, and culture in modern society. In M. Battiste (Ed.). Reclaiming Indigenous Voice and Vision. pp. 192-208. University of British Columbia Press, Vancouver, Canada.

Baynam, G., C. Molster, A. Bauskis, E. Kowal, R. Savarirayan, M. Kelaher, S. Easteal, L. Massey and G. Garvey. 2017. Indigenous genetics and rare diseases: Harmony, diversity and equity. In: M. Posada de la Paz, D. Taruscio and S. C. Groft (Eds.). Rare Diseases Epidemiology: Update and Overview. pp. 511-520. Springer, Cham, Switzerland. doi: 10.1007/978-3-319-67144-4.
Beaudoin, J. M., L. Bouthillier, and G. Chiasson. 2015. Growing deep roots: Increasing Aboriginal authority in contemporary forest governance arrangements. Land Use Pol. 49: 287-295. doi: 10.1016/ j.landusepol.2015.08.004.

Bernos, T. A., K. M. Jeffries and N. E. Mandrak. 2020. Linking genomics and fish conservation decision making: A review. Rev. Fish. Biol. Fisheries 30(4): 587-604. doi: 0.1007/s11160-020-09618-8. Bernatchez, L., M. Wellenreuther, C. Araneda, D. T. Ashton, J. M. I. Barth, T. D. beacham, G. E. Maes, J. T. Martinsohn and K. M. Miller. 2017. Harnessing the power of genomics to secure the future of seafood. Trends Ecol. Evol. 32(9): 665-680. doi:10.1016/ j.tree.2017.06.010.

Berrang-Ford, L., J. D. Ford and J. Paterson. 2011. Are we adapting to climate change? Global Environ. Change 21(1): 25-33. doi: 10.1016/j.gloenvcha.2010.09.012.

Bilodeau, P., A. D. Roe, G. Bilodeau, G. S. Blackburn, M. Cui, M. Cusson, D. Doucet, V. C. Griess and M. A. Lafond. 2019. Biosurveillance of forest insects: Part II-adoption of genomic tools by end user communities and barriers to integration. J. Pest Sci. 92(1): 71-82. doi: 10.1007/s10340-018-1001-1.

Borrell, J. S., J. Zohren, R. A. Nichols and R. J. Buggs. 2019. Genomic assessment of local adaptation in dwarf birch to inform assisted gene flow. Evol. Appl. 13(1): 161-175. doi:10.1111/ eva.12883

Bowles, E., K. Marin, S. Mogensen., P. MacLeod and D. J. Fraser. 2020a. Size reductions and genomic changes within two generations in wild walleye populations: Associated with harvest? Evol. Appl. 13(6): 1128-1144. doi: 10.1111/eva.12987.

Bowles, E., K. Marin, P. MacLeod and D. J. Fraser. 2020b. A three-pronged approach that leans on Indigenous knowledge for northern fish monitoring and conservation. Evol. Appl. (20201031). doi: 10.1111/eva.13146.

Bozhkov, E., C. Walker, V. McCourt and H. Castleden. 2020. Are the natural sciences ready for truth, healing, and reconciliation with Indigenous peoples in Canada? Exploring 'settler readiness' at a world-class freshwater research station. J. Environ. Studies Sci. 10(3): 226-241. doi: 10.1007/s13412-020-00601-0.

Cardinale, B. J., J. E. Duffy, A. Gonzalez, D. U. Hooper, C. Perrings, P. Venail, A. Narwani, G. M. Mace and D. Tilaman. 2012. Biodiversity loss and its impact on humanity. Nature 486(7401): 5967. doi: 10.1038/nature11148.

Casas, A., J. Cruse-Sanders, E. Morales, A. Otero-Arnaiz and A. Valiente-Banuet. 2006. Maintenance of phenotypic and genotypic diversity in managed populations of Stenocereus stellatus (Cactaceae) by indigenous peoples in Central Mexico. Biodivers. Conserv. 15(3): 879-898. doi: 10.1007/s10531-004-2934-7.

Chamberland, V., F. Robichaud, M. Perron, N. Gélinas, J. Bousquet and J. Beaulieu. 2020. Conventional versus genomic selection for white spruce improvement: a comparison of costs and benefits of plantations on Quebec public lands. Tree Genet. Genomes. 16(1), 1-16. doi:10.1007/s11295-019-1409-7.

Claw, K. G., M. Z. Anderson, R. L. Begay, K. S. Tsosie, K. Fox and G. Nanibaa'A. 2018. A framework for enhancing ethical genomic research with Indigenous communities. Nat. Commun. 9(1): 1-7. doi: 10.1038/s41467-018-05188-3.

Collier-Robinson, L., A. Rayne, M. Rupene, C. Thoms and T. Steeves. 2019. Embedding indigenous principles in genomic research of culturally significant species. N. Z. J. Ecol. 43(3): 1-9. doi: 10.20417/nzjecol.43.36.

Crann, S. E., C. Fairley, D. Badulescu, W. W. Mohn and K. C. O'Doherty. 2015. Soils, microbes, and forest health: A qualitative analysis of social and institutional factors affecting genomic technology adoption. Technol. Soc. 43: 1-9. doi: 10.1016/j.techsoc.2015.06.001. Creswell, J. W. 2014. Research design: Qualitative, quantitative, and mixed methods approaches. 4th ed. 273 p. SAGE Publications Inc., Thousand Oaks, CA. 
Cullingham, C. I., J. K. Janes, R. C. Hamelin, P. M. James, B. W. Murray and F. A. Sperling. 2018. The contribution of genetics and genomics to understanding the ecology of the mountain pine beetle system. Can. J. For. Res. 49(7): 721-730. doi: 10.1139/cjfr-2018-0303. Dalton, J. E. 2006. Aboriginal self-determination in Canada: Protections afforded by the judiciary and government. Can. J. Law Soc. 21(1): 11-37. doi: 10.1353/jls.2006.0034.

Datta, R. 2018. Decolonizing both researcher and research and its effectiveness in Indigenous research. Res. Ethics 14(2): 1-24. doi: $10.1177 / 1747016117733296$.

Degner J. 2020. Local Adaptation in the Interior Spruce Hybrid Complex. In: I. Porth, A. De la Torre (Eds.). The Spruce Genome. pp. 155-176. Compendium of Plant Genomes. Springer, Cham. Switzerland. doi:10.1007/978-3-030-21001-4_10.

Descola, P. 2005. Par-delà nature et culture. 792 p. Éditions Gallimard, Paris, France.

Downing, A. and A. Cuerrier. 2011. A synthesis of the impacts of climate change on the First Nations and Inuit of Canada. Indian J. Tradit. Know. 10(1): 57-70.

Dupont, P. P., V. Bourret and L. Bernatchez. 2007. Interplay between ecological, behavioural and historical factors in shaping the genetic structure of sympatric walleye populations (Sander vitreus). Mol. Ecol. 16(5): 937-951. doi: 10.1111/j.1365-294X.2006.03205.x.

Fauvelot, C., F. Bertozzi, F. Costantini, L. Airoldi and M. Abbiati. 2009. Lower genetic diversity in the limpet Patella caerulea on urban coastal structures compared to natural rocky habitats. Mar. Biol. 156(11): 2313-2323. doi: 10.1007/s00227-009-1259-1.

Finogentova, O. E., O. V. Belaya and J. A. Kitsai. 2020. Ethical and Legal Issues of Genetic Research of Indigenous Small-Numbered Peoples. In: T. Kolmykova and E. V. Kharchenko (Eds.). Digital Future Economic Growth, Social Adaptation, and Technological Perspectives. pp. 301-310. Springer, Cham. doi: 10.1007/978-3-03039797-5.

Fraser, D. J., A. M. Calvert, L. Bernatchez and A. Coon. 2013. Multidisciplinary population monitoring when demographic data are sparse: A case study of remote trout populations. Ecol. Evol. 3(15): 4954-4969. doi: 10.1002/ece3.871.

Fraser, D. J., T. Coon, M. R. Prince, R. Dion and L. Bernatchez. 2006. Integrating traditional and evolutionary knowledge in biodiversity conservation: A population level case study. Ecol. Soc. 11(2). doi: 10.5751/ES-01754-110204.

Funk W. C., K. R. Zamudio and A. J. Crawford. 2018. Advancing Understanding of Amphibian Evolution, Ecology, Behavior, and Conservation with Massively Parallel Sequencing. In: P. A. Hohenlohe and O. P. Rajora (Eds.). Population Genomics: Wildlife. pp. 211-254. Springer, Cham. doi: 10.1007/13836_2018_61.

Funk, W. C., B. R. Forester, S. J. Converse, C. Darst and S. Morey. 2019. Improving conservation policy with genomics: A guide to integrating adaptive potential into US Endangered Species Act decisions for conservation practitioners and geneticists. Conserv. Genet. 20(1): 115-134. doi: 10.1007/s10592-018-1096-1.

Furgal, C., D. Martin and P. Gosselin. 2002. Climate Change and Health in Nunavik and Labrador: Lessons from Inuit Knowledge. In: I. Krupnik and D. Jolly (Eds.). The Earth is Faster Now: Indigenous Observations of Arctic Environmental Change. pp. 266-300. Arctic Research Consortium of the United States, Arctic Studies Centre, Smithsonian Institution, Washington, D.C.

Garrison, N., K. S. Barton, K. M. Porter, T. Mai, W. Burke and S. R. Carroll. 2019a. Access and management: Indigenous perspectives on genomic data sharing. Ethnic. Dis. 29(Supp): 659-668. doi: 10.18865/ed.29.S3.659.

Garrison, N. A., M. Hudson, L. L. Ballantyne, I. Garba, A. Martinez, M. Taualii, L. Arbour, N. R. Caron and S. T. Rainie. 2019b. Genomic research through an Indigenous lens: Understanding the expectations. Annu. Rev. Genomics Hum. Genet. 20: 495-517. doi: 10.1146/annurev-genom-083118-015434.
Gearheard, S., M. Pocernich, R. Stewart, J. Sanguya and H. P. Huntington. 2010. Linking Inuit knowledge and meteorological station observations to understand changing wind patterns at Clyde River, Nunavut. Clim. Change 100(2): 267-294. doi: 10.1007/ s10584-009-9587-1.

Geary, J., C. G. Jardine, J. Guebert and T. Bubela. 2013. Access and benefits sharing of genetic resources and associated traditional knowledge in northern Canada: Understanding the legal environment and creating effective research agreements. Intern. J. Circumpol. Healt. 72(1): 21351. doi: 10.3402/ijch.v72i0.21351.

GIEC. 2014. Changements climatiques 2014: Rapport de synthèse. Groupe d'experts intergouvernemental sur l'évolution du Climat (GIEC), Genève, Suisse. 161 p.

Girard, C. and C. Brisson. 2014. Nitassinan Notre Terre: Alliance et souveraineté partagée du peuple innu au Québec; des premiers contacts à nos jours. 175 p. Les Presses de l'Université Laval, Québec, Qc.

Godbout, J., M. C. Gros-Louis, M. Lamothe and N. Isabel. 2019. Going with the flow: Intraspecific variation may act as a natural ally to counterbalance the impacts of global change for the riparian species Populus deltoides. Evol. Appl. 13(1): 176-194. doi:10.1111/ eva.12854

Golden, D. M., C. Audet and M. A. Smith. 2015. "Blue-ice": Framing climate change and reframing climate change adaptation from the indigenous peoples' perspective in the northern boreal forest of Ontario, Canada. Clim. Devel. 7(5): 401-413. doi: 10.1080/ 17565529.2014.966048.

Henare, K. L., K. E. Parker, H. Wihongi, C. Blenkiron, R. Jansen, P. Reid, M. P. Findlay, B. Lawrernce and M. Hudson. 2019. Mapping a route to Indigenous engagement in cancer genomic research. Lancet Oncol. 20(6): e327-e335. doi: 10.1016/S14702045(19)30307-9.

Hoegh-Guldberg, O. and J. F. Bruno. 2010. The impact of climate change on the world's marine ecosystems. Science 328(5985): 15231528. doi: $10.1126 /$ science. 1189930 .

Holderegger, R., N. Balkenhol, J. Bolliger, J. O. Engler, F. Gugerli, A. HochKirch, C. Nowak, G. Segelbacher and A. Widmer. 2019. Conservation genetics: Linking science with practice. Mol. Ecol. 28(17): 3848-3856. doi: 10.1111/mec.15202.

Homburger, J. R., A. Moreno-Estrada, C. R. Gignoux, D. Nelson, E. Sanchez, P. Ortiz-Tello, B. A. Pons-Estel, E. Acevedo-Vasquez and P. Miranda. 2015. Genomic insights into the ancestry and demographic history of South America. PLoS Genet. 11(12): e1005602. doi: 10.1371/journal.pgen.1005602.

Housty, W. G., A. Noson, G. W. Scoville, J. Boulanger, R. M. Jeo, C. T. Darimont and C. E. Filardi. 2014. Grizzly bear monitoring by the Heiltsuk people as a crucible for First Nation conservation practice. Ecol. Soc. 19(2). doi: 10.5751/ES-06668-190270.

Hudson, M., N. A. Garrison, R. Sterling, N. R. Caron, K. Fox, J. Yracheta, J. Anderson, P. Wilcox and L. Arbour. 2020. Rights, interests and expectations: Indigenous perspectives on unrestricted access to genomic data. Nat. Rev. Genet. 1-8. doi: 10.1038/s41576020-0228-X.

Huntington, H. P., R. S. Suydam and D. H. Rosenberg. 2004. Traditional knowledge and satellite tracking as complementary approaches to ecological understanding. Environ. Conserv. 31(3): 177-180. doi: 10.1017/S0376892904001559.

Ingvarsson, P. K. and C. Bernhardsson. 2019. Genome-wide signatures of environmental adaptation in European aspen (Populus tremula) under current and future climate conditions. Evol. Appl. 13(1): 132-142. doi: 10.1111/eva.12792.

Isabel, N., J. A. Holliday and S. N. Aitken. 2019. Forest genomics: Advancing climate adaptation, forest health, productivity, and conservation. Evol. Appl. 13(1): 3-10. doi: 10.1111/eva.12902.

Jackson, N. D. and L. Fahrig. 2011. Relative effects of road mortality and decreased connectivity on population genetic diversity. Biol. Conserv. 144(12): 3143-3148. doi: 10.1016/j.biocon.2011.09.010. 
Kadykalo, A. N., S. J. Cooke and N. Young. 2020. Conservation genomics from a practitioner lens: Evaluating the research-implementation gap in a managed freshwater fishery. Biological Conservation. 241: 108350. doi: 10.1016/j.biocon.2019.108350.

King, U. and C. Furgal. 2014. Is hunting still healthy? Understanding the interrelationships between indigenous participation in landbased practices and human-environmental health. Int. J. Environ. Res. Public Health. 11(6): 5751-5782. doi: 10.3390/ijerph110605751. Kovach, M. 2009. Indigenous methodologies: Characteristics, conversations and contexts. 201 p. University of Toronto Press, Toronto, Canada.

Kowal, E., G. Pearson, C. S. Peacock, S. E. Jamieson and J. M. Blackwell. 2012. Genetic research and aboriginal and Torres Strait Islander Australians. J. Bioethic. Inq. 9(4): 419-432. doi: 10.1007/ s11673-012-9391-x.

Larson, W. A., D. A. Isermann and Z. S. Feiner. 2020. Incomplete bioinformatic filtering and inadequate age and growth analysis lead to an incorrect inference of harvested-induced changes. Evol. Appl. (20200912). doi: 10.1111/eva.13122.

Lévesque, C., P. Apparicio and É. Cloutier. 2013. Favoriser la coconstruction des connaissances en contexte autochtone : enjeux et défis méthodologiques. In: C. Lévesque, É. Cloutier and D. Salée (Eds.). La coconstruction des connaissances en contexte autochtone: cinq études de cas. pp. 47-52. Cahier no 2013-03. DIALOG, Montréal, Qc.

Lenz, P. R., S. Nadeau, M. J. Mottet, M. Perron, N. Isabel, J. Beaulieu and J. Bousquet. 2019. Multi-trait genomic selection for weevil resistance, growth, and wood quality in Norway spruce. Evol. Appl. 13(1): 76-94. doi:10.1111/eva.12823.

Lindo, J., A. Achilli, U. A. Perego, D. Archer, C. Valdiosera, B. Petzelt, J. Mitchell, R. Worl and E. J. Dixon. 2017. Ancient individuals from the North American Northwest Coast reveal 10,000 years of regional genetic continuity. Proc. Natl. Acad. Sci. 114(16): 4093-4098. doi: 10.1073/pnas.1620410114.

Lundmark, C., K. Andersson, A. Sandström and L. Laikre. 2017. Effectiveness of short-term knowledge communication on Baltic Sea marine genetic biodiversity to public managers. Reg. Environ. Change. 17(3): 841-849. doi: 10.1007/s10113-016-1077-1.

Lundmark, C., A. Sandström, K. Andersson and L. Laikre. 2019. Monitoring the effects of knowledge communication on conservation managers' perception of genetic biodiversity-A case study from the Baltic Sea. Marine Policy 99: 223-229. doi: 10.1016/j.marpol.2018.10.023.

Mahony, C. R., I. R. MacLachlan, B. M. Lind, J. B. Yoder, T. Wang and S. N. Aitken. 2019. Evaluating genomic data for management of local adaptation in a changing climate: A lodgepole pine case study. Evol. Appl. 13(1): 116-131. doi: 10.1111/eva.12871.

Maltais, V. 2010. Analyse sociopolitique des socio-économiques liés à la génomique forestière : Étude de cas du Québec. M.Sc. thesis, Département des sciences du bois et de la forêt, Université Laval, Québec, Qc. 64 p.

Marin, K., A. Coon and D. J. Fraser. 2017. Traditional ecological knowledge reveals the extent of sympatric lake trout diversity and habitat preferences. Ecol. Soc. 22(2). doi: 10.5751/ES-09345-220220. Martin, T. and A. Girard. 2009. La forêt matrice de culture: Analyse des mémoires déposés à la commission Coulombe par les premières nations du Québec. Recherches amérindiennes au Québec 39(1-2): 61-70. doi: 10.7202/044997ar.

McGregor, D. 2018. From 'decolonized' to reconciliation research in Canada: Drawing from Indigenous research paradigms. ACME: An International Journal for Critical Geographies 17(3): 810-831.

McWhirter, R., D. Nicol and J. Savulescu. 2015. Genomics in research and health care with Aboriginal and Torres Strait Islander peoples. Monash Bioethics Rev. 33(2-3): 203-209. doi: 10.1007/s40592-015-0037-8.

Morgan, J., R. R. Coe, R. Lesueur, R. Kenny, R. Price, N. Makela and P. H. Birch. 2019. Indigenous peoples and genomics: Starting a conversation. J. Genet. Couns. 28(2): 407-418. doi: 10.1002/ jgc4.1073.
Nadeau, S., J. Godbout, M. Lamothe, M. C. Gros-Louis, N. Isabel and K. Ritland. 2015. Contrasting patterns of genetic diversity across the ranges of Pinus monticola and P. strobus: A comparison between eastern and western North American postglacial colonization histories. Am. J. Bot. 102(8): 1342-1355. doi: 10.3732/ ajb. 1500160 .

Nelson, E. J., P. Kareiva, M. Ruckelshaus, K. Arkema, G. Geller, E. Girvetz, D. Goodrich, V. Matzek and M. Pinsky. 2013. Climate change's impact on key ecosystem services and the human well-being they support in the US. Front. Ecol. Environ. 11(9): 483893. doi: $10.1890 / 120312$.

Newmaster, S. G. and S. Ragupathy. 2010. Ethnobotany genomicsdiscovery and innovation in a new era of exploratory research. J. Ethnobiol. Ethnomed. 6(1): 2. doi: 10.1186/1746-4269-6-2.

Nickels, S., C. Furgal, M. Buell and H. Moquin. 2005. Unikkaaqatigiit: Putting the Human Face on Climate Change-Perspectives from Inuit in Canada. Joint publication of Inuit Tapiriit Kanatami, Nasivvik Centre for Inuit Health and Changing Environments at Université Laval and the Ajunnginiq Centre at the National Aboriginal Health Organization. Ottawa. 123 p.

Nilausen, C., N. Gélinas and G. Bull. 2016. Perceived acceptability of implementing marker-assisted selection in the forests of British Columbia. Forests 7(11): 286. doi: 10.3390/f7110286.

Organisation des Nations unies (ONU). 2007. Déclaration des Nations Unies sur les droits des peuples autochtones. 30 p. New York, NY.

Ostapchuk, J., S. Harper, A. C. Willox and V. L. Edge. 2012. Exploring Elders' and Seniors' Perceptions of How Climate Change is Impacting Health and Well-being in Rigolet, Nunatsiavut/

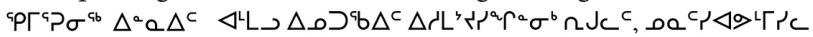

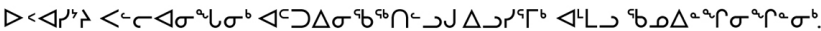
Intern. J. Indigenous Healt. 9(2): 6-24. doi: 10.18357/ijih92201214358. Pardo, R., C. Midden and J. D. Miller. 2002. Attitudes toward biotechnology in the European Union. J. Biotechnol. 98(1): 9-24. doi: 10.1016/S0168-1656(02)00082-2.

Paul, J. and A. R. Criado. 2020. The art of writing literature review: What do we know and what do we need to know? Intern. Bus. Rev. 101717. doi: 10.1016/j.ibusrev.2020.101717.

Percy, C., M. Isaac and C. Pamela. 2010. Understanding the relationship between indigenous (traditional) knowledge systems (IKS) and access to genetic resources and benefits sharing (ABS). Afr. J. Biotechnol. 9(54): 9204-9207. doi: 10.5897/AJB2010.000-3346.

Polfus, J. L., M. Manseau, D. Simmons, M. Neyelle, W. Bayha, F. Andrew, L. Andrew, C. F. C. Klütsch and K. Rice. 2016. Leghagots' enete (learning together) the importance of indigenous perspectives in the identification of biological variation. Ecol. Soc. 21(2). doi: 10.5751/ES-08284-210218.

Polfus, J. L., D. Simmons, M. Neyelle, W. Bayha, F. Andrew, L. Andrew, B. G. Merkle, K. Rice and M. Manseau. 2017. Creative convergence: exploring biocultural diversity through art. Ecol. Soc. 22(2). doi: 10.5751/ES-08711-220204.

Porth, I., G. Bull, S. Ahmed, Y. El-Kassaby and M. Boyland. 2015. Forest genomics research and development in Canada: Priorities for developing an economic framework. For. Chron. 91(1): 60-70. doi: 10.5558/tfc2015-011.

Porth, I., G. Bull, J. Cool, N. Gélinas and V. C. Griess. 2016. An economic assessment of genomics research and development initiative projects in forestry. CAB Rev. 11(016): 1-10. doi: 10.1079/ PAVSNNR201611016.

Ragupathy, S., S. G. Newmaster, M. Murugesan and V. Balasubramaniam. 2009. DNA barcoding discriminates a new cryptic grass species revealed in an ethnobotany study by the hill tribes of the Western Ghats in southern India. Mol. Ecol. Resour. 9: 164-171. doi: 10.1111/j.1755-0998.2009.02641.x.

Rangan, H., K. L. Bell, D. A. Baum, R. Fowler, P. McConvell, T. Saunders, S. Spronck, C. A. Kull and D. J. Murphy. 2015. New genetic and linguistic analyses show ancient human influence on 
baobab evolution and distribution in Australia. PloS one 10(4): e0119758. doi: 10.1371/journal.pone.0119758.

Roe, A. D., A. S. Torson, G. Bilodeau, G. S. Blackburn, M. Cui, M. Cusson, D. Doucet and V. G. Griess. 2019. Biosurveillance of forest insects: Part I-integration and application of genomic tools to the surveillance of non-native forest insects. J. Pest Sci. 92(1): 51-70. doi: 10.1007/s10340-018-1027-4.

Rossetto, M., E. J. Ens, T. Honings, P. D. Wilson, J. Y. S. Yap, O. Costello, E. R. Round, R. M. Borges and C. Bowern. 2017. From songlines to genomes: Prehistoric assisted migration of a rain forest tree by Australian Aboriginal people. PloS one. 12(11): e0186663. doi: 10.1371/journal.pone.0186663.

Rosol, R., S. Powell-Hellyer and H. M. Chan. 2016. Impacts of decline harvest of country food on nutrient intake among Inuit in Arctic Canada: Impact of climate change and possible adaptation plan. Intern. J. Circumpol. Heal. 75(1): 31127. doi: 10.3402/ ijch.v75.31127.

Sanchez Badini, O., R. Hajjar and R. Kozak. 2018. Critical success factors for small and medium forest enterprises: A review. For. Pol. Econ. 94: 35-45. doi: 10.1016/j.forpol.2018.06.005.

Sangha, K. K., L. Preece, J. Villarreal-Rosas, J. J. Kegamba, K. Paudyal, T. Warmenhoven and P. S. RamaKrishnan. 2018. An ecosystem services framework to evaluate Indigenous and local peoples' connections with nature. Ecosystem Serv. 31: 111-125. doi: 10.1016/j.ecoser.2018.03.017.

Schmidt, P. M. and M. J. Peterson. 2009. Biodiversity conservation and indigenous land management in the era of self-determination. Conserv. Biol. 23(6): 1458-1466. doi: 10.1111/j.15231739.2009.01262.x.

Schuttenberg, H. Z. and H. K. Guth. 2015. Seeking our shared wisdom: A framework for understanding knowledge coproduction and co-productive capacities. Ecol. Soc. 20(1): 15. doi: 10.5751/ES07038-200115.

Sederoff, R., A. Myburg and M. Kirst. 2009. Genomics, domestication, and evolution of forest trees. Cold Spring Harbor Symposia on Quantitative Biology 74: 303-317. doi: 10.1101/sqb.2009.74.040.

Shafer, A. B., J. B. W. Wolf, P. C. Alves, L. Bergström, M. W. Bruford, I. Brännström, G. Colling, L. Dalén and L. De Meester. 2015. Genomics and the challenging translation into conservation practice. Trends Ecol. Evol. 30(2): 78-87. doi: 10.1016/j.tree.2014. 11.009.

Skoglund, P., C. Posth, K. Sirak, M. Spriggs, F. Valentin, S. Bedford, G. R. Clark, C. Reepmeyer and F. Petchey. 2016. Genomic insights into the peopling of the Southwest Pacific. Nature. 538(7626): 510-513. doi: 10.1038/nature19844.

Smith, L. T. 1999. Decolonizing methodologies: Research and indigenous peoples. $1^{\text {st }}$ ed. 208 p. Zed Books, New York, USA.

Smith, T. G. 2000. Identifying the Stocks of Belugas in Nunavik: The Role of Genetics. Published by Makivik Corporation under the Aboriginal Fisheries Strategy Program of the Department of Fisheries and Oceans. 24 p.

Sork, V. L., S. N. Aitken, R. J. Dyer, A. J. Eckert, P. Legendre and D. B. Neale. 2013. Putting the landscape into the genomics of trees: approaches for understanding local adaptation and population responses to changing climate. Tree Genetic. Genomes 9(4): $901-$ 911. doi: 10.1007/s11295-013-0596-x.

Straub, E. T. 2009. Understanding technology adoption: Theory and future directions for informal learning. Rev. Educat. Res. 79(2): 625-649. doi: 10.3102/0034654308325896.

Stronen, A. V., E. L. Navid, M. S. Quinn, P. C. Paquet, H. M. Bryan and C.T. Darimont. 2014. Population genetic structure of gray wolves (Canis lupus) in a marine archipelago suggests islandmainland differentiation consistent with dietary niche. BMC ecology. 14(1): 11. doi: 10.1186/1472-6785-14-11.

Taft, H. R., D. N. McCoskey, J. M. Miller, S. K. Pearson, M. A. Coleman, N. K. Fletcher, C. S. Mittan, M. H. Meek and S. Barbosa. 2020. Research-management partnerships: An opportunity to integrate genetics in conservation actions. Conserv. Sci. Prac. 2(9): e218. doi: 10.1111/csp2.218.

TallBear, K. 2013a. Native American DNA: Tribal belonging and the false promise of genetic science. 252 p. University of Minnesota Press, Minneapolis, MN.

TallBear, K. 2013b. Genomic articulations of indigeneity. Soc. Stud. Sci. 43(4): 509-533. doi: 10.1177/0306312713483893.

Taylor, H. R., N. Dussex and Y. van Heezik. 2017. Bridging the conservation genetics gap by identifying barriers to implementation for conservation practitioners. Global Ecol. Conserv. 10: 231-242. doi: 10.1016/j.gecco.2017.04.001.

Thomas, J. and A. Harden. 2008. Methods for the thematic synthesis of qualitative research in systematic reviews. BMC Med. Res. Methodol. 8(1): 45. doi: 10.1186/1471-2288-8-45.

Tomimatsu, H., S. R. Kephart and M. Vellend. 2009. Phylogeography of Camassia quamash in western North America: Postglacial colonization and transport by indigenous peoples. Mol. Ecol. 18(18): 3918-3928. doi: 10.1111/j.1365-294X.2009.04341.x.

Torterotot, J. B., C. Perrier, N. E. Bergeron and L. Bernatchez. 2014. Influence of forest road culverts and waterfalls on the finescale distribution of brook trout genetic diversity in a boreal watershed. Trans. Am. Fish. Soc. 143(6): 1577-1591. doi: 10.1080/ 00028487.2014 .952449 .

Touchette, L. 2020. Co-développement de savoirs autochtones et scientifiques : la génomique au service de la protection et de la conservation des forêts. Mémoire de fin d'études, Département des sciences du bois et de la forêt, Université Laval, Québec, Qc. 87 p.

TwoTrees, K. S. and M. Kolan. 2016. The trees are breathing us: an indigenous view of relationship in nature and business. In: G. A. Rosile (Ed.). Tribal Wisdom for Business Ethics. pp. 211-222. Emerald Group Publishing Limited. doi: 10.1108/978-1-78635-288020161009.

Ward-Fear, G., B. Rangers, D. Pearson, M. Bruton and R. Shine. 2019. Sharper eyes see shyer lizards: Collaboration with indigenous peoples can alter the outcomes of conservation research. Conservation Letters 12(4): e12643. doi: 10.1111/conl.12643.

Westbrook, J. W., Q. Zhang, M. K. Mandal, E. V. Jenkins, L. E. Barth, J. W. Jenkins, J. Grimwood, J. Schmutz and J. A. Holliday. 2019. Optimizing genomic selection for blight resistance in American chestnut backcross populations: A trade-off with American chestnut ancestry implies resistance is polygenic. Evol. Appl. 13(1): 31-47. doi: 10.1111/eva.12886.

Wyatt, S. 2008. First Nations, forest lands, and "aboriginal forestry" in Canada: From exclusion to co-management and beyond. Can. J. For. Res. 38(2): 171-180. doi: 10.1139/X07-214.

Wyatt, S., M. Kessels and F. van Laerhoven. 2015. Indigenous peoples' expectations for forestry in New Brunswick: Are rights enough? Soc. Nat. Resour. 28(6): 625-640. doi: 10.1080/08941920. 2014.970735.

Yannic, G., M. H. St-Laurent, J. Ortego, J. Taillon, A. Beauchemin, L. Bernatchez, C. Dussault and S. D. Côté. 2016. Integrating ecological and genetic structure to define management units for caribou in Eastern Canada. Conserv. Genet. 17(2): 437-453. doi: 10.1007/s10592-015-0795-0.

Zavala, M. 2013. What do we mean by decolonizing research strategies? Lessons from decolonizing, Indigenous research projects in New Zealand and Latin America. Decolonization: Indigeneity, Education \& Society. 2(1): 55-71.

Zhang, J. J. 2017. Research ethics and ethical research: some observations from the Global South. J. Geog. High. Educat. 41(1): 147154. doi: 10.1080/03098265.2016.1241985.

Zuercher, G. L., P. S. Gipson and G. C. Stewart. 2003. Identification of carnivore feces by local peoples and molecular analyses. Wildlife Soc. Bull. 31(4): 961-970. doi: 10.2307/3784440. 